DOI: 10.20472/EFC.2019.012.017

\title{
MATEUSZ MOKROGULSKI
}

Warsaw School of Economics, Poland

\section{MACROPRUDENTIAL POLICY IN POLAND}

\begin{abstract}
:
The main objective of this paper is to present macroprudential measures introduced in Poland compared to other EU Member States. Macroprudential policy is applied to strengthen the resilience of the financial system in case of materialisation of systemic risk and to support long-term sustainable economic growth. In Poland a lot of effort has been made to address the problem of Swiss franc loans. Due to increasing risk weights for FX portfolios, banks have to maintain much more capital to address systemic risk compared to domestic-currency portfolios. Other macroprudential policy instruments were set to evaluate the systemic importance of large banks operating in Poland. Nevertheless, supervisory authorities from Central and Eastern European countries do not have full flexibility in implementing macroprudential policy instruments.
\end{abstract}

\section{Keywords:}

macroprudential policy, capital buffer, risk weights, banking sector, systemic risk, financial stability

JEL Classification: D04, G21, G28 


\section{Introduction}

Macroprudential policy in Poland has been officially pursued since the fourth quarter of 2015 when the Act on Macroprudential Supervision of the Financial System and Crisis Management came into force. Since that time all macroprudential measures can be officially applied in Poland. That kind of policy is run in all EU Member States on the basis of 2 legal acts:

- Regulation (EU) No 575/2013 of the European Parliament and of the Council of 26 June 2013 on prudential requirements for credit institutions and investment firms and amending regulation (EU) No 648/2012 (CRR),

- Directive 2013/36/EU of the European Parliament and of the Council of 26 June 2013 on access to the activity of credit institutions and the prudential supervision of credit institutions and investment firms, amending Directive 2002/87/EC and repealing Directives 2006/48/EC and 2006/49/EC (CRD).

The abovementioned Act on Macroprudential Supervision of the Financial System and Crisis Management enabled implementation of the CRD to the Polish legislation. Before that the Polish Financial Supervision Authority (KNF), undertook a lot of actions that were in fact macroprudential.

In general macroprudential instruments serve to strengthen the resilience of the financial system in case of materialisation of systemic risk and to support long-term sustainable economic growth. Nowadays a prevalent macroprudential policy tool are capital buffers that are now used across EU countries. However, Poland and other Central and Eastern European countries do not have full flexibility when calibrating particular instruments as the CRD introduces caps on certain buffer rates for banks that are subsidiaries of EU parent institutions. Macroprudential policy in Poland has also served to solve the problem of foreign-exchange residential mortgage loans (FX loans). However, the results here are not optimistic.

The main objective of this paper is thus to present macroprudential measures introduced in Poland compared to other EU Member States. 


\section{Literature review}

Macroprudential policy is considered to be the answer to the existence of systemic risk, that is intrinsically linked with contagion, macroeconomic shocks and unwinding of imbalances (ECB 2009). A common consensus is that systemic risk mainly stems from the fact of interconnectedness of a particular bank with other financial institutions. The wider the range of interbank market activities of a particular bank, the bigger its systemic importance (Drehmann, Tarashev, 2013).

First opinions on the necessity to run macroprudential policy were expressed as early as in the beginning of the XXI century. The objective of a macroprudential approach was to limit the risk of episodes of financial distress with significant losses in terms of the real output for the economy as a whole (Borio 2003). The author also made clear distinction between microprudential and macroprudential perspectives. The first group of actions is addressed to limit distress of individual institutions and may prove insufficient when the risk is of a systemic type. Conversely, macroprudential policy actions should limit financial system-wide distress and this definition of macroprudential policy has persisted. Nevertheless, currently more attention is drawn to the problem of strengthening the resilience of the financial sector (ECB 2019). That kind of policy should be focused on mitigating systemic risks that follow from: excessive credit growth and leverage, excessive maturity mismatch and market illiquidity, direct and indirect exposure concentrations, as well as misaligned incentives and moral hazard (ESRB 2014). Although microprudential and macroprudential policy objectives may overlap (ECB 2018), it is now proposed that pillar 2 should serve for microeconomic purposes.

Since macroprudential policy is a new kind of policy that is pursued across EU Member States, it is too early to find empirical example of the influence of that kind of policy on the stability of the financial sector as a whole. However, certain research has been done for the real estate market, where macroprudential regulatory instruments are believed to serve against real estate bubbles (Hartmann 2015). Macroprudential policy instruments should definitely be applied to large banks. Such institutions are usually interconnected with other financial institutions are their collapse will inevitably have adverse effect on both the financial system and the real economy. Moreover, when an institution exceeds certain size, the risk that it generates grows non-linearly (Tarashev et al. 2010, Moore and Zhou 2014, Black et al. 2016), so big banks should 
possess larger capital resources compared to smaller ones than it just results from their size.

\section{Capital buffers}

The most common tool of macroprudential policy are capital buffers. They serve to restrict lending activities as banks are obliged to maintain more capital compared to regulatory and microprudential requirements. The banks are then forced to accumulate capital in the way that is described in figure 1.

\section{Figure 1: Composition of capital requirements}

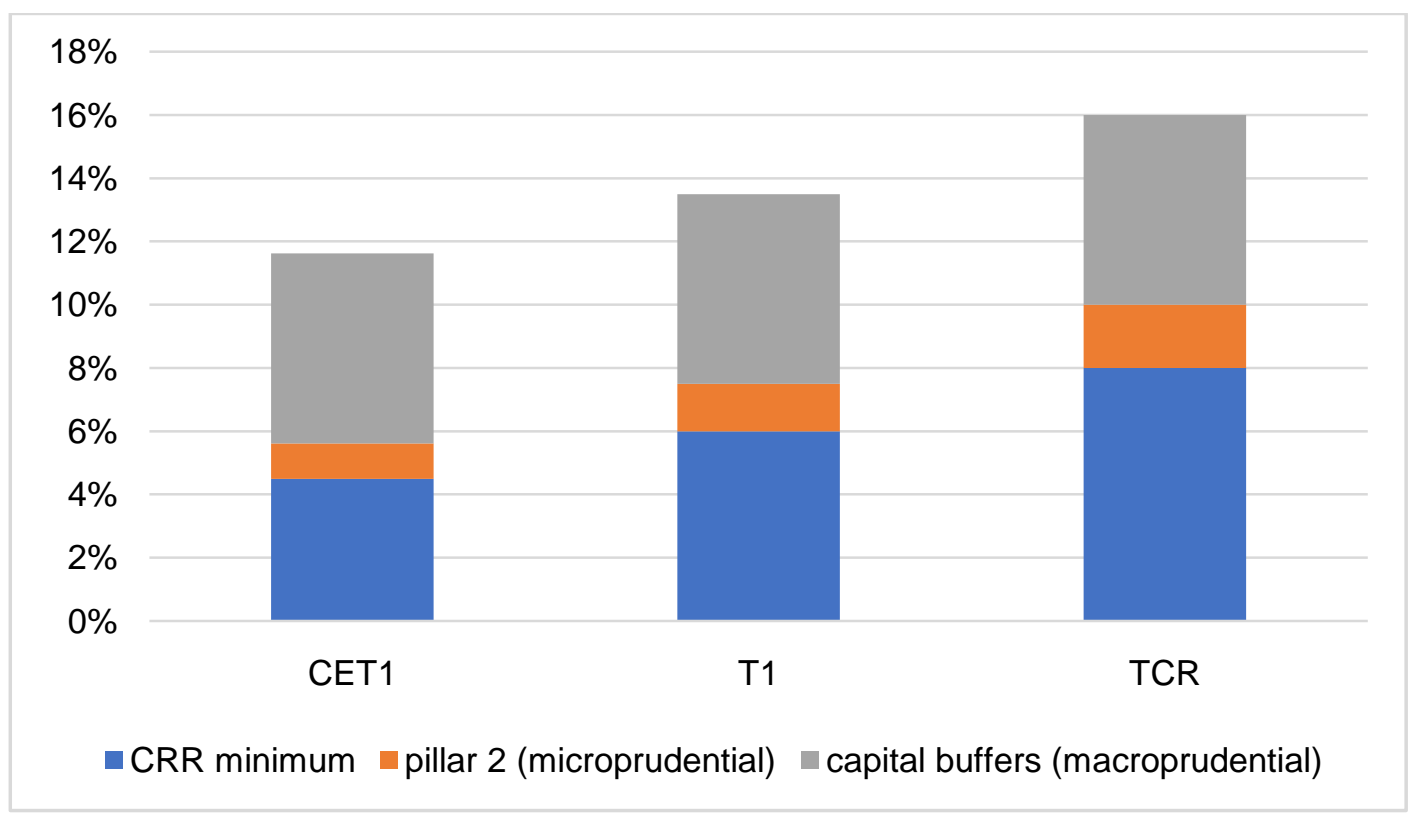

Source: Own elaboration

CET1 (Common Equity Tier 1) is the highest-quality capital and is mainly composed of shares issued by the bank and retained earnings. T1 (Tier 1) capital represents the sum of CET1 and Additional Tier 1 (AT1) instruments that are convertible into CET1 capital when a particular trigger occurs. However, in Poland such instruments are absent in commercial banks due to certain legal obstacles. Finally, TCR (total capital ratio) is the sum of $\mathrm{T} 1$ and T2 (tier 2), where the latter is mainly composed of subordinate debt. Each bank has individual capital requirements that are based on its size, composition of the portfolio and the credit cycle of a particular economy. Although sometimes it is difficult to make clear distinction between microprudential 
and macroprudential nature of the risk, pillar 2 and capital buffers should not overlap. In article 128 of the CRD the following capital buffers are defined:

- capital conservation buffer (CCB),

- institution-specific countercyclical capital buffer (CС)B),

- global systemically important institutions (G-SII) buffer,

- other systemically important institutions (O-SII) buffer,

- systemic risk buffer (SyRB).

The above buffers, where applicable, sum up to the combined buffer requirements. In Poland the latter is between $5.5 \%$ and $6.5 \%$ of total risk exposure. The difference stems from systemic importance of the bank measured by the O-SII buffer ${ }^{1}$. Below a few characteristics of each buffer are presented.

\section{Capital conservation buffer}

That buffer rate is uniform across banks. Starting from 2019 its target value of $2.5 \%$ of total risk exposure has been reached. Because of the clearly defined level of that buffer, there is no need to calibrate its value.

\section{$\underline{\text { Countercyclical capital buffer }}$}

That buffer is set when credit growth in a particular Member State is considered excessive. The initial value for that buffer rate is equal to zero. Then, each Member State is empowered to set a buffer at a positive level not exceeding $2.5 \%$ of total risk exposure $^{2}$. Recently more and more Member States have been taking advantage of that macroprudential policy tool and 12 EU countries altogether (plus Norway and Iceland) have decided to set that buffer: Belgium, Bulgaria, Czech Republic, Denmark, France, Germany, Ireland, Lithuania, Luxembourg, Slovakia, Sweden and United Kingdom. In Poland the CСуB has not been activated so far as the credit activity of the banks is not sufficiently high compared to the nominal GDP growth.

\footnotetext{
${ }^{1}$ There are also some discrepancies between banks in Poland regarding the values of CCyB rates (due to operations carried out outside Poland, i.e. in those Member States where CCyB has been introduced) and SyRB rates (due to the fact that this buffer has only been set on exposures located in Poland), but the differences are just minor.

${ }^{2}$ In extreme cases the CCyB rate can exceed $2.5 \%$.
} 


\section{$\underline{\text { G-SIl buffer }}$}

Global systemically important institutions (G-SIls) are the ones that are large, complex and usually operate in a variety of countries. Those banks are obliged to maintain additional capital buffers in order to avoid problems generated by too-big-to-fail institutions, which was prevalent before the recent financial crises. The systemic importance of a banking group is evaluated on the basis of 5 categories $^{3}$ :

- size of the group,

- interconnectedness of the group with the financial system,

- substitutability of the services or of the financial infrastructure provided by the group,

- complexity of the group,

- cross-border activity of the group, including cross-border activity between Member States and between a Member State and a third country.

On that basis each bank is assigned an individual score that informs about its systemic importance. The scores are then transformed into precise values of buffer rates. Nevertheless, only banks whose total exposures are at least equal to $200 \mathrm{bn}$ EUR are taken into consideration. The procedure of setting this buffer rate is fully standardised across all Member States. A maximum theoretical value of the buffer is equal to $3.5 \%$ of total risk exposure. In each EU country there are designated authorities (in Poland it is KNF - Polish Financial Supervision Authority) responsible for running the entire process. However, none of the supervisory authorities located in the new EU Member States participate in the process (see: table 1). That is because of the fact that the entire identification process is done at the highest consolidation level of a particular banking group. It means that if a bank $X$ from a country $A$ of the EU owns another bank $Y$ located in EU country $B$, it is the national competent authority in the country A (rather than the country B) that decides on the G-SII regarding the entire banking group ${ }^{4}$. For the purpose of that process the bank $Y$ is treated as if it were a part of the bank X. In fact it is not as subsidiaries that represent a part of the banking group are still a different legal entity. Since many banks located in Central and Eastern Europe are owned by banking group from EU15, the former are excluded from that process. That fact puts supervisory authorities from new EU

\footnotetext{
${ }^{3}$ Art. 131(2) of the CRD.

${ }^{4}$ It is assumed here that the bank $X$ in the country $A$ is an ultimate parent institution.
} 
Member States at a clear disadvantage as different supervisory authorities decide on certain macroprudential policy tools that indirectly refer to the banks actually supervised by them.

Table 1. G-SII buffers across EU. Selected data as of August 2019

\begin{tabular}{|l|c|c|c|}
\hline \multirow{2}{*}{ Country } & \multirow{2}{*}{ G-SIls - No. } & \multicolumn{2}{c|}{ Buffer rate (\%) } \\
\cline { 3 - 4 } & & $\min$ & $\max$ \\
\hline France & 4 & 1.00 & 1.50 \\
\hline Germany & 1 & 2.00 & 2.00 \\
\hline Italy & 1 & 1.00 & 1.00 \\
\hline Netherlands & 1 & 1.00 & 1.00 \\
\hline Spain & 1 & 1.00 & 1.00 \\
\hline UK & 3 & 1.00 & 2.00 \\
\hline
\end{tabular}

Source: Own elaboration based on the European Systemic Risk Board (ESRB) information

\section{$\underline{\text { O-SII buffer }}{ }^{5}$}

Similarly to the G-SII buffer, the procedure of setting O-SIl buffers on banks consists of 2 stages. First, the designated authority of each Member State should decide which banks are to be considered other systemically important institutions. The decisions here are based on the respective guidelines issued by the European Banking Authority (EBA/GL/2014/10) ${ }^{6}$ on $16^{\text {th }}$ December 2014. The document, which is uniform across all Member States, introduces the following indicators that are used to assess the systemic importance of particular banks (see: table 2).

Table 2: Obligatory indicators specified in the EBA guidelines to identify O-SIls

\begin{tabular}{|l|l|c|}
\hline \multicolumn{1}{|c|}{ Criterion } & \multicolumn{1}{c|}{ Indicators } & Weight \\
\hline Size & Total assets & $25 \%$ \\
\hline \multirow{2}{*}{$\begin{array}{l}\text { Importance (including } \\
\text { substitutability / financial } \\
\text { system infrastructure) }\end{array}$} & Value of domestic payment transactions & $8.33 \%$ \\
\cline { 2 - 3 } & Private sector deposits from depositors in the EU & $8.33 \%$ \\
\cline { 2 - 3 } $\begin{array}{l}\text { Complexity / cross-border } \\
\text { activity }\end{array}$ & Private sector loans to recipients in the EU & $8.33 \%$ \\
\cline { 2 - 3 } & Value of OTC derivatives (notional) & $8.33 \%$ \\
\hline
\end{tabular}

\footnotetext{
${ }^{5}$ The description of O-SII buffers is based on Mokrogulski (2017).

${ }^{6}$ See: EBA (2014).
} 


\begin{tabular}{|l|l|l|}
\hline & Cross-jurisdictional claims & $8.33 \%$ \\
\hline \multirow{3}{*}{ Interconnectedness } & Intra-financial system liabilities & $8.33 \%$ \\
\cline { 2 - 3 } & Intra-financial system assets & $8.33 \%$ \\
\cline { 2 - 3 } & Debt securities outstanding & $8.33 \%$ \\
\hline
\end{tabular}

Source: European Banking Authority

Banks are automatically designated as other systemically important institutions when their score at least equals 350 bps (out of 10,000$)^{7}$. It indicates a minimum market share of $3.5 \%$ (a weighted average with reference to the indicators and their weights in table 2). It is also possible to add other banks to that list on the basis of optional indicators.

The second stage of the procedure is to set the O-SII buffer, which cannot exceed $2 \%$ of the total risk exposure ${ }^{8}$. Nevertheless, it is not the only restriction. For banks that are subsidiaries of EU parent institutions the O-SII buffer rate cannot exceed the higher of ${ }^{9}$ :

- $1 \%$,

- respective G-SIl or O-SIl buffer rate of the EU parent company.

The abovementioned cap is especially material for new EU Member States (including Poland) where many subsidiaries or branches of banks from Western European countries operate. That upper limit seems unjustified. For example, suppose that a bank whose ultimate parent company is located in EU15 country (A) is not very large in global terms. However, that bank has a subsidiary in one of the new EU countries (B) and that subsidiary plays a significant role in the banking sector of that Member State. Then, a supervisory authority from the country B cannot set the O-SII buffer rate at a sufficiently high level because of the abovementioned cap. Hence, due to specific EU regulations, Central and Eastern European countries do not have full flexibility in supervising their banking sectors.

Currently the CRD is under the amendment process. Certain material changes are also prepared on the O-SII topic. On 16 ${ }^{\text {th }}$ April 2019 the European Parliament approved the final agreement on a package of reforms proposed by the European Commission. The CRD represents one element of that package. The main changes

\footnotetext{
${ }^{7}$ Each Member State has an option to adjust a cut-off score within an interval between 275 and 425 bps. However, a majority of countries applies a threshold of 350 bps.

${ }^{8}$ Art. 131(5) of the CRD.

${ }^{9}$ Art. $131(8)$ of the CRD.
} 
with respect to the O-SII buffer are the following. First, the maximum value for the OSIl buffer rate is going to be increased from $2 \%$ to $3 \%$. It gives more flexibility to the designated authorities in setting the appropriate buffers for supervised banks. Moreover, the buffer rate can even exceed $3 \%$, but such a decision is subject to the authorisation by the European Commission. Second, the cap for subsidiaries of EU parent companies is going to be modified, i.e. the maximum level of the buffer rate cannot exceed the lower of:

- the sum of the higher of the G-SII or the O-SII buffer rate applicable to the group on a consolidated basis and 1\%,

- $3 \%$.

The amended restriction for the O-SII buffer is believed to give more flexibility to host supervisors in setting the O-SII buffer rate. Nevertheless, some level of dependence of supervisory authorities from Central and Eastern European countries from consolidating supervisors from Western European countries is going to be maintained. In case of that macroprudential policy tool more national discretion rather than full harmonisation is definitely needed at the EU level. Selected data on O-SIls in all Member States are presented in table 3.

Table 3: Other systemically important institutions in EU Member States. Selected data as of August 2019

\begin{tabular}{|l|c|c|c|l|c|c|c|}
\hline \multirow{2}{*}{ Country } & \multirow{2}{*}{$\begin{array}{c}\text { O-Slls - } \\
\text { No. }\end{array}$} & \multicolumn{2}{|c|}{ Buffer rate (\%) } & \multirow{2}{*}{ Country } & \multirow{2}{*}{ O-SIls - No. } & \multicolumn{2}{|c|}{ Buffer rate (\%) } \\
& & $\min$ & $\max$ & & & $\min$ & $\max$ \\
\hline Austria & 9 & 1.00 & 2.00 & Italy & 3 & 0.25 & 1.00 \\
\hline Belgium & 8 & 0.75 & 1.50 & Latvia & 5 & 1.25 & 2.00 \\
\hline Bulgaria & 10 & 0.50 & 1.00 & Lithuania & 4 & 1.00 & 2.00 \\
\hline Croatia & 7 & 0.20 & 2.00 & Luxembourg & 8 & 0.50 & 2.00 \\
\hline Cyprus & 5 & 0.50 & 1.50 & Malta & 3 & 0.50 & 2.00 \\
\hline Czech Rep. & 7 & 0.00 & 0.00 & Netherlands & 5 & 1.00 & 2.00 \\
\hline Denmark & 7 & 0.00 & 0.00 & Poland & 11 & 0.00 & 1.00 \\
\hline Estonia & 4 & 1.00 & 2.00 & Portugal & 6 & 0.25 & 1.00 \\
\hline Finland & 3 & 0.50 & 2.00 & Romania & 9 & 1.00 & 2.00 \\
\hline France & 6 & 0.25 & 1.50 & Slovakia & 5 & 0.50 & 1.00 \\
\hline Germany & 13 & 0.50 & 2.00 & Slovenia & 6 & 0.25 & 1.00 \\
\hline
\end{tabular}




\begin{tabular}{|l|c|c|c|l|c|c|c|} 
Greece & 4 & 1.00 & 1.00 & Spain & 5 & 0.25 & 1.00 \\
\hline Hungary & 8 & 0.50 & 2.00 & Sweden & 4 & 2.00 & 2.00 \\
\hline Ireland & 6 & 0.00 & 1.50 & UK & 14 & 0.00 & 0.00 \\
\hline
\end{tabular}

Source: Own elaboration on ESRB information

\section{Systemic risk buffer}

The systemic risk buffer may be introduced with a view to preventing and mitigating long-term non-cyclical systemic risk. SyRB is thus complementary to the countercyclical capital buffer. Currently that macroprudential instrument is launched in 14 Member States including Poland (see: table 4).

Table 4. SyRB across EU. Selected data as of August 2019

\begin{tabular}{|l|c|c|}
\hline \multicolumn{1}{|c|}{ Country } & Systemic risk buffer & Buffer rate (\%) \\
\hline Austria & 13 banks & $1.00-2.00$ \\
\hline Bulgaria & sector & 3.00 \\
\hline Croatia & sector & $1.50-3.00$ \\
\hline Czech Republic & 5 banks & $1.00-3.00$ \\
\hline Denmark & 7 banks & $1.00-3.00$ \\
\hline Estonia & sector & 1.00 \\
\hline Finland & sector & $1.00-3.00$ \\
\hline Hungary & 2 banks & 0.00 \\
\hline Netherlands & 5 banks & $0.00-3.00$ \\
\hline Poland & sector & 3.00 \\
\hline Romania & sector & $0.00-2.00$ \\
\hline Slovakia & 3 banks & 1.00 \\
\hline Sweden & 4 banks & 3.00 \\
\hline UK & 5 banks & $1.00-2.00$ \\
\hline
\end{tabular}

Source: own elaboration on ESRB information 


\section{Polish solutions ${ }^{10}$ with respect to O-SIls}

In Poland the O-SII identification process is in line with the abovementioned EBA guidelines. In case of the buffer calibration, a proportional method has been applied, according to the following formula:

$$
r_{\text {OSII }}=\left\{\begin{array}{c}
{\left[\frac{w}{350}\right] \cdot 0.25 \% \text { if } w<1750} \\
2 \% \text { if } w \geq 1750
\end{array}\right.
$$

where:

rosII denotes the O-SII buffer, and $w$ is the score of a particular bank in basis points (for all institutions the basis points sum up to 10,000), and the square bracket denotes a mathematical operation of rounding down to the nearest whole number.

Such a methodology of calibrating the O-SII buffer means that the banks have been divided into several groups (buckets) according to their score. The buffer rate increases proportionally until the score reaches $1,750 \mathrm{bps}$. Then, the rate grows more than proportionally from $1.00 \%$ to $2.00 \%$, rather than from $1.00 \%$ to $1.25 \%$.

When clear definitions of intervals for basis points and respective O-SII buffer rates are disclosed, banks can evaluate possible costs and benefits of mergers and acquisitions. The cost here would stem from higher capital requirements for a larger bank, which adversely affects the supply of loans and profits from that activity. Setting the O-SII buffer automatically creates a kind of the opportunity cost for the bank and may serve as a threat before a decision of a possible merger. However, if the CRD is amended and the caps for O-SII buffers are increased, that methodology will have to be adjusted accordingly.

\section{The problem of CHF mortgage loans in Poland}

A lot of attention has been drawn to solving the problem of foreign-exchange residential mortgage loans (FX loans) ${ }^{11}$. The current volume of residential mortgage

\footnotetext{
${ }_{11}^{10}$ On the basis of KNF (2016).

${ }^{11}$ It is worth mentioning that FX residential mortgage loans are not truly "FX loans". That is because they have been originated to consumers in the domestic currency, rather than directly in the foreign currency. Banks made additional profits on that as the exchange rates that were used for conversions differed substantially from average market exchange rates (so called bank spreads).
} 
loans in Poland is estimated at 426.6 bn PLN ${ }^{12}$ at the end of 2019-Q1. Domesticcurrency loans represent $69.4 \%$ of that number, CHF and EUR loans account for $24.3 \%$ and $5.3 \%$ respectively (see: figure 2 ). It is the CHF loans that are of paramount importance as sharp appreciation of that currency increased the value of monthly instalments that consumers have to repay to the bank. The current CHF/PLN rate is fluctuating between 3.80-4.00, whereas between January 2006 and July 2008, when large volumes of CHF loans were issued, it levelled off at $1.96-2.63$. The share of $\mathrm{CHF}$ loans has been gradually diminishing due to the natural process of repayments. In 2011-Q4, when that volume reached its peak, it represented $52.2 \%$ of all residential mortgage loans.

\section{Figure 2: Residential mortgage loans in Poland (data in bn PLN)}

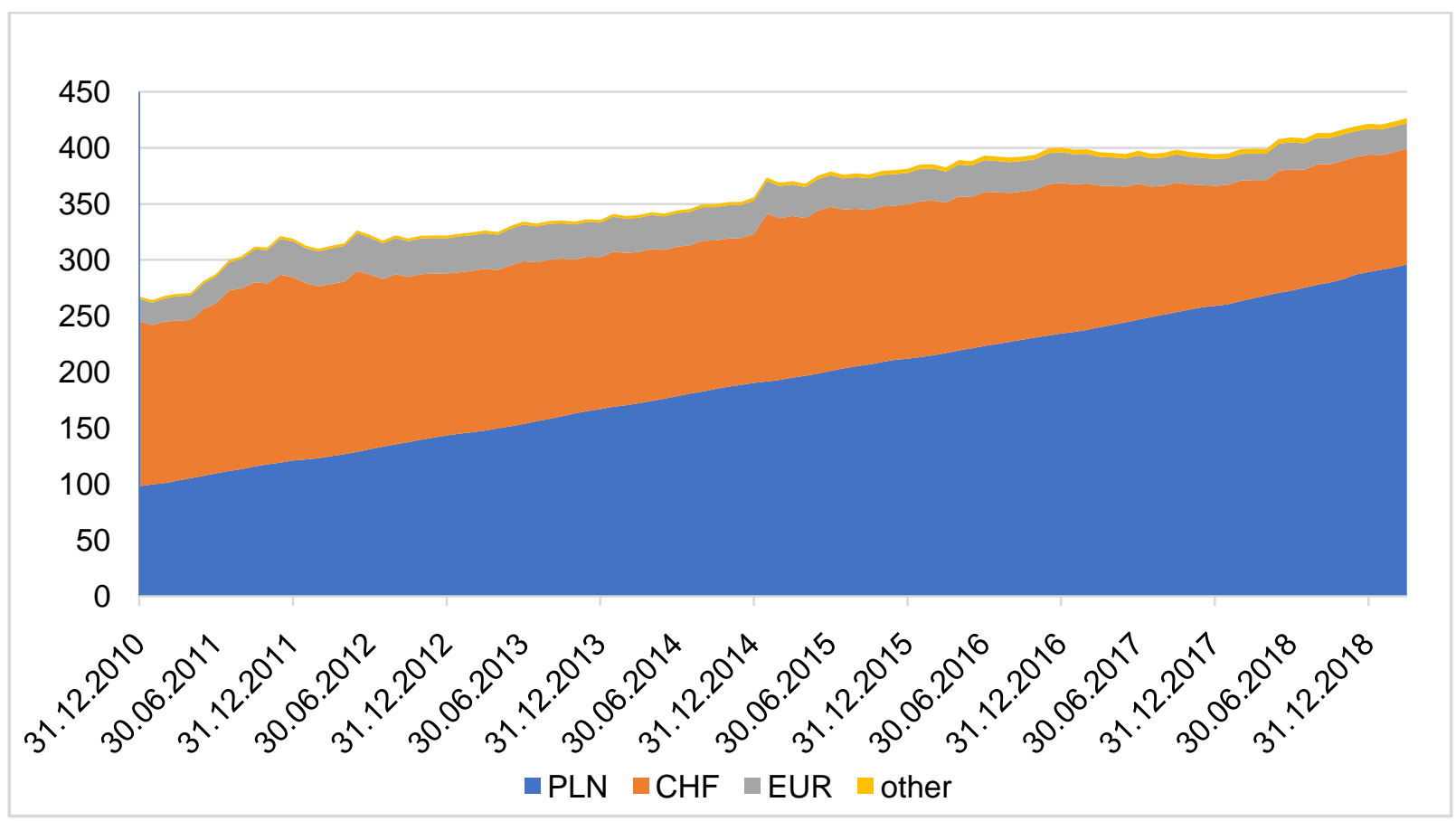

Source: Own elaboration based on KNF data.

In order to eliminate the CHF loans from bank balance sheets, it has been decided to take advantage of macroprudential policy tools. On $13^{\text {th }}$ January 2017 the Financial Stability Committee (KSF) which is a competent authority for macroprudential policy in Poland stated that the FX housing loans portfolio did generate systemic risk especially in the context of their mandatory conversion into the domestic-currency loans (PLN loans). According to the Committee the conversion should only be of the voluntary

${ }^{12}$ Equivalent to 99.2 bn EUR. 
basis. That is why the Committee issued 9 recommendations altogether ${ }^{13}$ with a view to providing banks with both legal and economic incentives for voluntary conversions. 5 recommendations were addressed to the minister competent for financial institutions (the Minister of Finance), 3 recommendations to the Polish Financial Supervision Authority, and one recommendation to the Bank Guarantee Fund. The decision of the Committee was preceded by a variety of actions undertaken by the KNF. In 2006 a, so called, Recommendation $\mathrm{S}$ was issued. This document required banks that grant $\mathrm{FX}$ loans to apply more stringent criteria when calculating creditworthiness of clients compared to domestic-currency loans. The recommendation also increased the risk weights for FX loans from $35 \%$ to $75 \%$. The risk weights were further shifted to $100 \%$ in 2011. Furthermore, due to intense activity of the KNF, FX loans were practically eliminated from banks' offers. They were only allowed to those customers who receive permanent incomes in the currency of the loan. New mortgage loans that are issued in the domestic currency are characterised by a loan-to-value (LtV) parameter not exceeding $80 \%{ }^{14}$. Thus, the actions taken by the KNF before 2016 were in fact macroprudential, although from the legal point of view the macroprudential policy could not be run at that time.

Owing to the successful implementation of one of the Committee's recommendation, risk weights have been further increased. For FX exposures that are secured by mortgages on residential property they now stand at $150 \%$ compared to $35 \%$ for PLN loans ${ }^{15}$. A risk weight of $150 \%$ is the maximum amount that is allowed according to the art. 124 of the CRR. However, such a risk weight only applies to banks that calculate their capital requirements according to the standardised (STA) approach. A few banks have permission to use the Internal Risk Based (IRB) Approach. Such a consent given by the KNF allows banks to take advantage of lower risk weights. Hence IRB banks have to maintain less capital than STA banks to cover credit risk, so they can engage in lending activities to a larger extent. In order to obtain the effect equivalent to raising the risk weights, one of the Financial Stability Committee's recommendations issued to the Minister of Finance referred to IRB banks. The Committee decided to increase the minimum value of the LGD (Loss Given Default) parameter that would be equivalent to raising risk weights for STA banks. The Committee stated that in order to

\footnotetext{
${ }^{13}$ NBP (2017).

${ }^{14}$ Or $90 \%$ if the loan is properly secured.

${ }^{15}$ According to art. 125(2)(d) of the CRR the risk weight of 35\% can be assigned if the loan does not exceed $80 \%$ of the market value of the property or $80 \%$ of the mortgage lending value of the property.
} 
fulfill this recommendation, certain legislative changes were necessary. However, those amendments have not taken place so far. That is why IRB banks still have advantage over STA banks located in Poland and this regulatory arbitrage has not been eliminated yet. Moreover, the KNF has not issued so far the supervisory recommendation on best practices for restructuring of those loans. Without that document banks find it difficult or even impossible to convert the FX loans into the domestic-currency ones.

There is, however, one recommendation addressed to the Minister of Finance that is only partially related to the problem of FX loans. It is the introduction of the systemic risk buffer (SyRB) equal to 3\% of the exposures located in Poland. That capital buffer has been set on all institutions, i.e. even on those banks that do not have FX loans in their portfolios (e.g. co-operative banks). That is why SyRB in Poland should be considered a supplementary rather than a direct tool of macroprudential policy that aims at reducing the FX mortgage portfolio. Nevertheless, SyRB is gaining popularity as a macroprudential policy tool across EU countries (see: table 4).

All the above macroprudential measures aim at accelerating the process of voluntary conversions. However, that has not in fact happened and there are a few reasons for that. First, banks are rather unwilling to convert the FX loans into PLN ones at the exchange rate that differs from the current market exchange rate. Second, consumers believe that the appropriate conversion rate is the one at which the loan has originally been granted. Many consumers are now demanding the conversion at exactly that rate. It is thus difficult to find the exchange rate that would be satisfactory for both banks and clients. And finally, politicians in Poland prepared a few legal acts on mandatory conversion of FX loans into PLN loans. So banks have refrained from providing their clients with attractive conversion offers as everybody has been waiting for possible legal acts on that topic. Now it is almost certain that mandatory conversion into PLN loans will not be supported by the Polish government.

\section{Conclusion}

1. Macroprudential policy is considered to be the answer to the existence of systemic risk that mainly stems from the fact of interconnectedness of a particular bank with other financial institutions. 
2. Macroprudential policy in Poland has been officially pursued since 2015-Q4. Before that the KNF undertook a variety of actions that were in fact macroprudential.

3. In Poland it is the O-SII buffer and the systemic risk buffer that have been introduced so far. The KNF provided the appropriate methodology to calculate the O-SII buffer rate.

4. Macroprudential policy is run in all EU Member States. Nevertheless, due to specific EU regulations Central and Eastern European countries do not have full flexibility in setting the capital buffers on systemically important banks.

5. In Poland a lot of attention has been drawn to solving the problem of foreignexchange residential mortgage loans (FX loans). However, macroprudential recommendations have not accelerated the process of voluntary conversions of those loans into domestic-currency ones.

6. Further empirical research on the influence of macroprudential policy on the stability of the financial sector and the long-term economic growth are now needed. 


\section{References}

Act of Macroprudential Supervision of the Financial System and Crisis Management, https://www.nbp.pl/macroprudentialsupervision/podstawa/eng_act_on_macroprudential_supervisi on.pdf, access 8 August 2019.

BLACK L., CORREA R., HUANG X., ZHOU H. (2016), The systemic risk of European banks during the financial and sovereign debt crises, Journal of Banking and Finance, Vol. 63, issue C, p. 107125.

BOARD OF GOVERNORS OF THE FEDERAL RESERVE SYSTEM (2015), Calibrating the GSIB Surcharge, https://www.federalreserve.gov/aboutthefed/boardmeetings/gsib-methodology-paper20150720.pdf, access 8 August 2019.

BORIO C. (2003), Towards a macroprudential framework for financial supervision and regulation?, BIS Working Papers, No. 128, February, Basel.

Directive 2013/36/EU of the European Parliament and of the Council of 26 June 2013 on access to the activity of credit institutions and the prudential supervision of credit institutions and investment firms, amending Directive 2002/87/EC and repealing Directives 2006/48/EC and 2006/49/EC.

DREHMANN, TARASHEV (2013), Measuring the systemic importance of interconnected banks, Journal of Financial Intermediation, Vol. 22, p. 586-607.

EFTHYVOULOU G., YILDIRIM C. (2013), Market Power in CEE Banking Sectors and the Impact of the Global Financial Crisis, Case Network Studies and Analyses, No. 452.

EUROPEAN BANKING AUTHORITY (EBA 2014), Guidelines on the criteria to determine the conditions of application of article 131(3) of directive 2013/36/eu (CRD) in relation to the assessment of other systemically important institutions (O-S/ls), https://www.eba.europa.eu/documents/10180/ 930752/EBA-GL-2014-10+(Guidelines+on+O-SIls+Assessment).pdf, access 8 August 2019.

EUROPEAN CENTRAL BANK (ECB), Statistical Data Warehouse, http://sdw.ecb.europa.eu/

EUROPEAN CENTRAL BANK (ECB 2019),

https://www.ecb.europa.eu/ecb/tasks/stability/html/index.en. html, access 8 August 2019.

EUROPEAN CENTRAL BANK (ECB 2018), A Review of Macroprudential Policy in the EU in 2017, April 2018.

EUROPEAN CENTRAL BANK (ECB 2009), The concept of systemic risk, Financial Stability Review, December, p. 134-142.

EUROPEAN SYSTEMIC RISK BOARD (ESRB), National Policy. National Macroprudential Institutional Framework, https://www.esrb.europa.eu/national_policy/html/index.en.html, access 8 August 2019. 
EUROPEAN SYSTEMIC RISK BOARD (ESRB 2014), Flagship Report on Macro-prudential Policy in the Banking Sector, https://www.esrb.europa.eu/pub/pdf/other/140303_flagship_report.pdf, access 8 August 2019.

HARTMANN (2015), Real Estate Markets and Macroprudential Policy in Europe, Journal of Money, Credit and Banking, Supplement to Vol. 47, No. 1, March-April.

KNF (POLISH FINANCIAL SUPERVISION AUTHORITY), database, https://www.knf.gov.pl/?articleld=56224\&p_id=18

KNF (POLISH FINANCIAL SUPERVISION AUTHORITY 2016), Skrócony opis metod służących ocenie nadzorczej przy identyfikacji innych instytucji o znaczeniu systemowym, https://www.knf.gov.pl/publikacje_i_opracowania/raporty_i_opracowania/bankowy?articleld=5623 6\&p_id=18, access 8 August 2019.

KRUSZKA M, MOKROGULSKI M. (2017), Capital Requirements for European Banks of the Systemic Importance, Vistula Scientific Quarterly, No. 1(51), p. 187-204.

MOKROGULSKI M. (2017), The application of macroprudential policy tools to affect concentration in the Polish banking sector, Proceedings of the $28^{\text {th }}$ International Academic Conference, Tel Aviv, https://www.iises.net/proceedings/28th-international-academic-conference-tel-aviv-israel/table-ofcontent/detail?article=the-application-of-macropru dential-policy-tools-to-affect-concentration-inthe-polish-banking-sector, access 8 August 2019.

MOORE K., ZHOU C. (2014), Determinants of Systemic Importance, SRC Discussion Paper No. 19, LSE, London.

NATIONAL BANK OF POLAND (NBP 2017), Press release of the Financial Stability Committee on implementation of the recommendation on FX housing loans portfolio restructuring, https://www.nbp.pl/nadzormakroostroznosciowy/podstawa/20170602en.pdf, access 8 August 2019.

Regulation (EU) No 575/2013 of the European Parliament and of the Council of 26 June 2013 on prudential requirements for credit institutions and investment firms and amending regulation (EU) No 648/2012.

TARASHEV N., BORIO C., TSATSARONIS K. (2010), Attributing systemic risk to individual institutions, BIS Working Papers, No. 308, May, Basel. 